JPE (Jurnal Pendidikan Edutama) Vol. 8 No. 2 Juli 2021

P-ISSN: 2339-2258 (Print) E-ISSN: 2548-821X (Online)

http://ejurnal.ikippgribojonegoro.ac.id/index.php/JPE

\title{
PENGEMBANGAN PENGUKURAN KESIAPAN PEMBELAJARAN ONLINE DENGAN PENDEKATAN DATA DEMOGRAFIS
}

\author{
Citra Kurniawan ${ }^{1}$, Zuhkhriyan Zakaria ${ }^{2}$ \\ ${ }^{1}$ Fakultas Ilmu Pendidikan, Universitas Negeri Malang \\ email: citra.kurniawan.fip@um.ac.id \\ ${ }^{2}$ Fakultas Agama Islam, Universitas Islam Malang \\ email: zakaria@unisma.ac.id
}

\begin{abstract}
Considering the rapid change in learning orientation towards digital-based learning, it is necessary to validate online learning readiness. Several previous studies have discussed the importance of measuring online learning readiness, but very few have discussed their approach with demographic data. This study uses a developmental study approach and validation of online learning readiness to evaluate how ready students are to face online learning. This study involved 450 students from two universities consisting of 122 male and 328 female. The three stages of research include reliability testing, validity testing and exploration of demographic data based on the validation results of online learning readiness measurements. This study answered three research questions: (1) How does the reliability of online learning readiness measurement?; (2) How does the validity of online learning readiness measurement?; (3) How does the demographic data on online learning readiness?. This study went through a systematic validation stage and found that the measurement of online learning readiness met the requirements for reliability and validity. Meanwhile, the results of the demographic data exploration found that there was no significant effect of gender differences on online learning readiness. However, further differences in study backgrounds present different results where the study program background gives positive results on several aspects of online learning readiness.
\end{abstract}

Keyword: online learning readiness, demographic, validity, reliability.

Abstrak: Mempertimbangkan perubahan orientasi pembelajaran yang cepat menuju pembelajaran berbasis digital maka diperlukan validasi kesiapan pembelajaran online. Beberapa penelitian terdahulu telah membahas bagaimana pentingnya pengukuran kesiapan pembelajaran online namun masih sedikit sekali yang membahas terkait pendekatannya dengan data demografis. Penelitian ini menggunakan pendekatan kajian perkembangan dan validasi kesiapan pembelajaran online untuk mengevaluasi seberapa siapkah mahasiswa menghadapi pembelajaran online. Penelitian ini melibatkan 450 mahasiswa dari dua perguruan tinggi yang terdiri dari 122 laki-laki dan 328 perempuan. Tiga tahap penelitian meliputi uji reliabilitas, uji validitas dan eksplorasi data demografis berdasarkan hasil validasi pengukuran kesiapan pembelajaran online. Penelitian ini menjawab tiga pertanyaan penelitian: (1) Bagaimana reliabilitas pengukuran kesiapan pembelajaran online?; (2) Bagaimana validitas pengukuran kesiapan pembelajaran online?; (3) Bagaimana data demografis terhadap kesiapan pembelajaran online?. Penelitian ini melalui tahapan validasi secara sistematis dan menemukan bahwa pengukuran kesiapan pembelaran online memenuhi syarat reliabel dan validitas. Sedangkan pada hasil explorasi data demografis ditemukan bahwa tidak terdapat pengaruh signifikan perbedaan jenis kelamin terhadap kesiapan pembelajaran online. Namun lebih lanjut pada perbedaan latar belakang studi menyajikan hasil yang berbeda dimana latar belakang program studi memberikan hasil positif terhadap beberapa aspek kesiapan pembelajaran online.

Kata Kunci: kesiapan pembelajaran online, demografis, validitas, reliabilitas. 


\section{PENDAHULUAN}

Pandemi covid-19 memberikan dampak yang cukup besar pada setiap aspek kehidupan, khususnya pada aspek pendidikan. Perubahan orientasi belajar secara cepat terjadi seiring adanya wabah pandemi di setiap daerah di Indonesia. Pandemi covid-19 memaksa semua aktivitas menghentikan kegiatannya yang diikuti dengan penutupan bangunan fisik sebagai tempat beraktifitas. Kebijakan pemerintah untuk membatasi aktivitas fisik di semua lingkungan masyarakat mendorong semua bidang bermigrasi pada platform online (Kementrian Kesehatan Republik Indonesia, 2020). Kebijakan tersebut tentu saja berdampak juga pada lingkungan pendidikan pada berbagai tingkatan pendidikan yang mengakibatkan perubahan metode pembelajaran tatap muka menjadi pembelajaran online. Dampak perubahan metode pembelajaran pada pembelajaran online ini didukung oleh Kementrian Pendidikan dan Kebudayaan Republik Indonesia yang menyatakan bahwa proses pembelajaran di Perguruan Tinggi (PT) diselenggarakan dengan metode pembelajaran jarak jauh sesuai dengan kondisi masing-masing PT (Kementerian Pendidikan dan Kebudayaan, 2020). Strategi pembelajaran yang sebelumnya berorientasi terhadap tatap muka berpindah menjadi pembelajaran berbasis daring (Santosa \& Sarwanta, 2021). Pernyataan tersebut sependapat dengan Muqsith \& Zainiyati (2021), diperlukannya sebuah bentuk adaptasi pembelajaran untuk menjaminkan keterlanjutan proses pembelajaran dengan cara beralih pada pembelajaran daring.

Perubahan metode pembelajaran mengakibatkan perubahan orientasi belajar menjadi pembelajaran berbasis digital. Perubahan ini tentu saya mengakibatkan banyak sekali kecemasan terhadap pembelajaran berbasis digital seperti pembelajaran online. Kecemasan menghadapi pembelajaran online muncul diakibatkan karena ketidaksiapan mahasiswa pada perubahan metode pembelajaran yang begitu cepat dan perubahan kebiasaan belajar yang baru. Kecemasan ini sangat berhubungan erat dengan kesiapan menghadapi pembelajaran online yang akan memberikan dampak peran negatif dalam proses pencapaian kinerja belajar online (Saadé, Kira, Mak, \& Nebebe, 2017). Keberagaman aspek yang dimiliki oleh setiap mahasiswa tentu mempengaruhi kesiapan untuk mereka menghadapi pembelajaran online. Perubahan orientasi belajar yang begitu cepat tidak selalu diimbangi dengan kesiapan untuk menghadapi pembelajaran online. Kesiapan pembelajaran online mempengaruhi terhadap peran aktif mahasiswa untuk mengikuti kelas pembelajaran online dan menyelesaikan tugas tepat waktu (Hung, Chou, Chen, \& Own, 2010). Pembelajaran online memberikan kesempatan mahasiswa untuk belajar lebih fleksibel dimanapun dan kapanpun mereka belajar. Selain itu pembelajaran online memberikan kendali penuh untuk mahasiswa dalam menentukan cara bagaimana mereka belajar dan menyelesaikan masalah dalam pembelajaran (Joosten \& Cusatis, 2020). Banyak studi memberikan fokus pada bagaimana kesiapan pembelajaran online ini dapat meningkatkan pencapaian hasil belajar. Namun, tetapi sedikit sekali studi yang mengkaitkan kesiapan belajar dengan perbedaan data demografis mahasiswa. Data demografis sebagai atribut mahasiswa diharapkan dapat memberikan hasil yang signifikan terhadap pengembangan dan validasi kesiapan pembelajaran online dengan pendekatan data demografis. Oleh sebab itu maka penelitian ini mengembangkan instrumen pengukuran kesiapan pembelajaran online pada mahasiswa. 


\section{Kesiapan Pembelajaran Online}

Kesiapan pembelajaran online mendapatkan perhatian seiring dengan pergeseran orientasi belajar secara cepat menuju pembelajaran online. Keberagaman atribut yang dimiliki mahasiswa menjadi salahsatu sebagai alasan mengapa kesiapan pembelajaran perlu untuk diukur. Model pengukuran kesiapan pembelajaran online menyajikan hubungan antar faktor yaitu motivasi diri, tanggung jawab diri, dan manajemen waktu, selain faktor kepercayaan diri mahasiswa yang mempengaruhi keberhasilan proses pembelajaran (Akaslan \& Law, 2011). Pada penelitian yang berbeda, keberhasilan pembelajaran online dipengaruhi oleh beberapa elemen utama seperti akses internet, efektifitas perangkat komputer, keahlian dalam mempergunakan komputer, keterampilan dan metode pembelajaran (Rasouli, Rahbania, \& Attaran, 2016). Pengembangan instrumen pengukuran kesiapan pembelajaran online menentukan indikator apa saja yang akan diukur. Menurut Aydin \& Tasci (2005), komponen yang mempengaruhi keberhasilan pembelajaran online yaitu (1) teknologi; (2) inovasi; (3) sumberdaya; dan (4) pengembangan diri. Teknologi menjadi komponen penunjang untuk melaksanakan proses pembelajaran online. Dengan adanya teknologi maka koneksi dan akses terhadap informasi dalam pembelajaran online menjadi mudah. Selain itu, teknologi berkembangkan pesat seiring dengan adanya inovasi dalam pembelajaran. Penggunaan teknologi pada pembelajaran dan pengajaran di institusi pendidikan tinggi memberikan dampak yang besar dalam proses belajar mengajar (Lai, 2011).

Integrasi teknologi pada proses belajar mengajar memiliki hubungan yang erat dengan pemanfaatan teknologi pembelajaran, dimana teknologi membantu dan mendukung pengajar dalam proses pembelajaran untuk melibatkan mahasiswa lebih aktif dan efektif (Ghavifekr \& Rosdy,
2015). Penggunaan teknologi dalam pembelajaran online dipercaya dapat mempermudah interaksi antar mahasiswa dan antar pengajar dengan mahasiswa. Penelitian yang dilakukan oleh Bovermann et al., (2018) mengindikasikan bahwa faktor yang menentukan keberhasilan interaksi, komunikasi dan hasil belajar online adalah elemen teknologi dan keterampilan komputer. Teknologi merupakan salah satu aspek yang perlu dipertimbangkan dalam mempersiapkan diri untuk melaksanan pembelaran online. Keterbatasan teknologi dapat menjadi salahsatu penyebab rendahnya tingkat partisipasi dan keberhasilan belajar mahasiswa terhadap pembelajaran online. Keterbatasan teknologi yang dimiliki mahasiswa berhubungan dengan keterampilan mahasiswa terhadap teknologi. Keterampilan teknis pada teknologi memiliki hubungan terhadap prestasi dan kinerja mahasiswa dalam lingkungan pembelajaran online, dimana dalam beberapa penelitian juga mengungkapkan bahwa adanya hubungan faktor kesiapan pembelajaran online terhadap prestasi belajar mahasiswa (Gigdem \& Osturk, 2016). Berdasarkan hal tersebut maka faktor kesiapan pembelajaran perlu untuk dipertimbangkan untuk diteliti. Kesiapan pembelajaran online dapat meliputi beberapa aspek yang perlu dikembangkan yaitu ketersediaan teknologi, tingkat penggunaan teknologi, kepercayaan diri, penerimaan terhadap teknologi, dan kebutuhan pelatihan penggunaan pembelajaran online (Ünal, Alir, \& Soydal, 2014). Namun pada penelitian tersebut masih perlu dikembangkan terutama pada keterlibatan atribut mahasiswa. Ketersediaan teknologi lebih dari bagaimana mengintegrasikan teknologi pada proses belajar mengajar tetapi juga mengubah proses belajar mengajar sehingga dapat meningkatkan pengalaman belajar mahasiswa (Turugare \& Rudhumbu, 2020). Ketersediaan teknologi dalam proses 
belajar mengajar memberikan dampak bagi pengajar dan mahasiswa yang meliputi cara berpikir kritis, pembelajaran mandiri, dan kemampuan pemrosesan infrormasi kognitif. Meskipun demikian, dampak teknologi terhadap keberhasilan belajar saat ini masih terdapat perbedaan argumen seperti penelitian yang dilakukan oleh Gagnon (2014) menyatakan bahwa tidak adanya hubungan langsung antara penggunaan teknologi dalam proses belajar mengajar dengan peningkatan kinerja mahasiswa. Aspek lain yang perlu dipertimbangkan adalah kepercayaan diri dan tingkat penerimaan teknologi. Kepercayaan diri terhadap penggunaan internet dan komputer terdiri dari konsep keterampilan, pengetahuan, sikap dan kompetensi memanfaatkan teknologi dalam rangka mewujudkan tujuan pembelajaran di lingkungan perguruan tinggi (Chung, Noor, \& Vloreen Nity Mathew, 2020). Penelitian ini membahas pertanyaan-penelitian sebagai berikut: (a) Bagaimana reliabilitas pengukuran kesiapan pembelajaran online?; (b) Bagaimana validitas pengukuran kesiapan pembelajaran online?; (c) Bagaimana data demografis terhadap kesiapan pembelajaran online?

\section{METODE PENELITIAN}

\section{Prosedur Penelitian}

Kesiapan untuk menggunakan pembelajaran online menjadi hal penting yang mempengaruhi tingkat keberhasilan strategi pembelajaran online. Alasan penting penelitian ini adalah untuk mengetahui kesiapan mahasiswa mengikuti kegiatan pembelajaran online. Penelitian ini menggunakan pendekatan statistik deskriptif dan visualisasi data untuk mengidentifikasi faktor utama penentu kesiapan pembelajaran online dan kecenderungan mahasiswa terhadap kesiapan pembelajaran online. Instrumen pengukuran kesiapan pembelajaran online yang dipergunakan pada penelitian ini merupakan pengembangan variabel beberapa item penelitian dari studi literatur penelitian sebelumnya (Akaslan \& Law, 2011; Aydin \& Tasci, 2005; Dray, Lowenthal, Miszkiewicz, Ruiz-Primo, \& Marczynski, 2011). Adapun kriteria-kriteria pengembangan instrument pengukuran adalah penyesuaian butir soal terhadap keadaan awal subjek penelitian seperti ketersediaan teknologi dan aplikasi yang dipergunakan di masing-masing fakultas dimana subjek penelitian menjalani proses pembelajaran. Proses awal yang dilakukan adalah kami meminta ahli teknologi pembelajaran untuk melakukan proses penilaian terhadap relevansi item dalam rangka kontruksi validitas intrumen. Proses kedua adalah melakukan uji coba terhadap instrumen yang telah divalidasi. Proses terakhir adalah melakukan analisis butir dengan menggunakan SPSS IBM Statistic 24 untuk membuktikan butir soal mana saja yang relevan dan memenuhi kriteria validitas, seperti yang ditunjukkan pada Gambar 1.

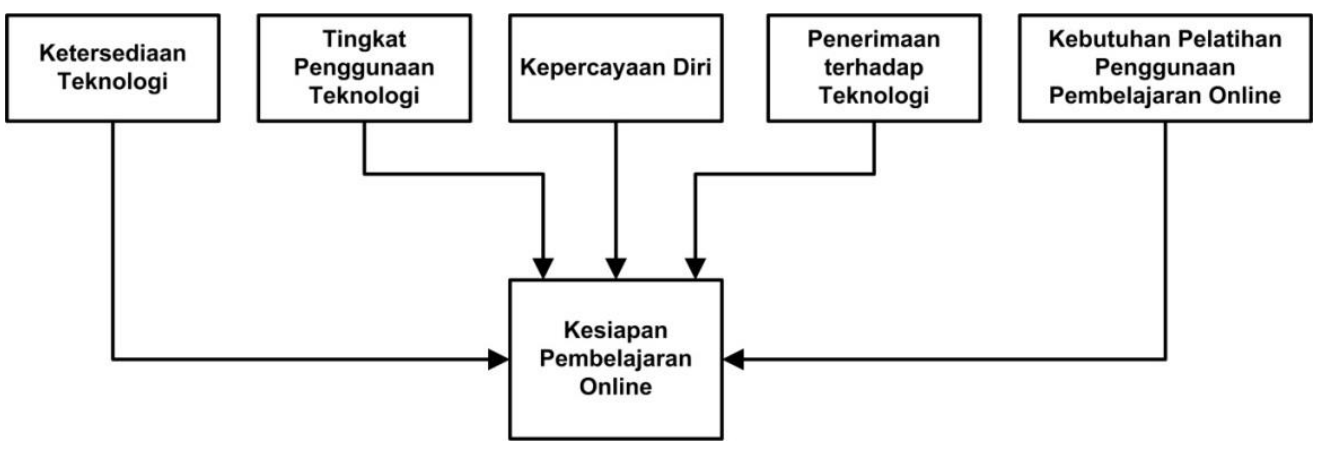

Gambar 1. Aspek kesiapan pembelajaran online 
Pada tahap awal, mahasiswa mengisi data demograsif dengan rincian pertanyaan: (1) nama lengkap; (2) program studi; dan (3) jenis kelamin. Selanjutnya mahasiswa diberikan kuisioner kesiapan pembelajaran online. Mahasiswa menyatakan tingkat persetujuan melalui pernyataan dalam skala kuisioner (1: Ya; 2: Tidak) dan mengidentifikasi 34 butir soal berdasarkan kondisi yang mereka alami dalam menghadapi pembelajaran online seperti yang ditunjukkan pada Tabel 1. Tabel 1 menunjukkan aspek penilaian kesiapan terhadap pembelajaran online, dimana setiap aspek diwakili oleh beberapa butir soal.
Tabel 1. Butir soal instrumen

\begin{tabular}{cl}
\hline Butir Soal & \multicolumn{1}{c}{ Aspek Penelitian } \\
\hline Q1 - Q6 & Ketersediaan Teknologi (KT) \\
\hline Q7-Q13 & $\begin{array}{l}\text { Tingkat Penggunaan Teknologi } \\
(\text { TPT })\end{array}$ \\
\hline Q14-Q25 & Kepercayaan Diri (KD) \\
\hline Q26-Q32 & $\begin{array}{l}\text { Penerimaan terhadap Teknologi } \\
\text { (PTP) }\end{array}$ \\
\hline Q33-Q34 & $\begin{array}{l}\text { Kebutuhan Pelatihan } \\
\text { Pembelajaran Online (KPPO) }\end{array}$ \\
\hline
\end{tabular}

Butir soal intrumen secara detail ditunjukkan pada Tabel 2.

Tabel 2. Butir soal instrumen kesiapan pembelajaran online

\begin{tabular}{cl}
\hline $\begin{array}{c}\text { Butir } \\
\text { Soal }\end{array}$ & \\
\hline Q1 & Fasilitas perangkat kerasnya sudah cukup. (Misal Komputer, Laptop, Tablet, dan handphone) \\
\hline Q2 & $\begin{array}{l}\text { Fasilitas perangkat lunaknya sudah cukup. (Misal Sistem Operasi windows, Aplikasi microsoft } \\
\text { office (word, excel, powerpoint), dan aplikasi pendukung yang lain) }\end{array}$ \\
\hline Q3 & Kecepatan akses internet memuaskan. \\
\hline Q4 & Stabilitas akses internet memuaskan. \\
\hline Q5 & Saya memiliki akses ke komputer kapan pun saya butuhkan. \\
\hline Q6 & Saya dapat menghubungkan internet kapan saja saya butuhkan. \\
\hline Q7 & Saya menggunakan perangkat lunak Office (mis. M.S. PowerPoint, Word, Excel). \\
\hline Q8 & $\begin{array}{l}\text { Saya menggunakan perangkat lunak tertentu (mis. SPSS, Photoshop, Coreldraw, Autocad, } \\
\text { Matlab atau pengkat lunak yang lain). }\end{array}$ \\
\hline Q9 & Saya menggunakan alat Web 2.0 (mis. Blog, wiki) untuk berbagi informasi. \\
\hline Q10 & Saya menggunakan layanan hosting file (mis. Google Documents, Dropbox, Google Drive, dll). \\
\hline Q11 & $\begin{array}{l}\text { Saya menggunakan sistem manajemen pembelajaran (mis. Edmodo, Moodle, Schology, Google } \\
\text { Class room atau media yang lain). }\end{array}$ \\
\hline Q12 & Saya menggunakan forum online dan mengobrol untuk berkomunikasi dengan kolega saya \\
\hline Q13 & Saya menggunakan teknologi seluler (mis. Smartphone, Tablet) untuk menghubungkan internet. \\
\hline Q14 & Saya memiliki informasi tentang apa itu pembelajaran online. \\
\hline Q15 & Saya memiliki keterampilan untuk mengoperasikan komputer. \\
\hline Q16 & $\begin{array}{l}\text { Saya dapat menggunakan perangkat lunak Office untuk pengiriman dan demonstrasi konten } \\
\text { (mis. M.S. Power Point, Word, Excel). }\end{array}$ \\
\hline Q17 & Saya dapat menggunakan browser web (mis. Internet Explorer, Google Chrome). \\
\hline Q18 & Saya dapat menggunakan mesin pencari (mis. Google, Bing, Yahoo, dll). \\
\hline Q19 & Saya dapat memecahkan sebagian besar masalah yang terkait dengan menggunakan komputer. \\
\hline Q20 & $\begin{array}{l}\text { Saya dapat menggunakan alat manajemen file digital (mis. Menghapus atau mengganti nama file } \\
\text { di komputer Anda). }\end{array}$ \\
\hline Q21 & Saya dapat mengerjakan pekerjaan rumah dengan menggunakan fasilitas teknologi elektronik. \\
\hline Q22 & $\begin{array}{l}\text { Saya punya cukup waktu untuk menyiapkan pekerjaan rumah dengan menggunakan fasilitas } \\
\text { teknologi elektronik. }\end{array}$ \\
\hline & \\
\hline
\end{tabular}




\begin{tabular}{ll}
\hline $\begin{array}{l}\text { Butir } \\
\text { Soal }\end{array}$ & \multicolumn{1}{c}{ Uraian } \\
\hline Q23 & $\begin{array}{l}\text { Saya dapat menggunakan sistem manajemen pembelajaran (mis. Edmodo, Moodle, Schology, } \\
\text { atau media yang lain). }\end{array}$ \\
\hline Q24 & Saya percaya bahwa pembelajaran online mudah digunakan. \\
\hline Q25 & Saya merasa bahwa saya siap untuk pembelajaran online. \\
\hline Q26 & Saya ingin memulai pembelajaran online. \\
\hline Q27 & Saya percaya bahwa pembelajaran online dapat meningkatkan kualitas pendidikan. \\
\hline Q28 & Saya percaya bahwa menggunakan pembelajaran online dapat meningkatkan produktivitas saya. \\
\hline Q29 & $\begin{array}{l}\text { Saya percaya bahwa pembelajaran online lebih efektif daripada pendekatan berbasis kelas } \\
\text { tradisional. }\end{array}$ \\
\hline Q30 & $\begin{array}{l}\text { Saya percaya bahwa pembelajaran online memungkinkan mahasiswa dan instruktur untuk } \\
\text { berkomunikasi dan berinteraksi lebih baik satu sama lain. }\end{array}$ \\
\hline Q31 & Saya percaya bahwa pembelajaran online memiliki manfaat untuk pendidikan. \\
\hline Q32 & Saya mendukung implementasi pembelajaran online di jurusan saya. \\
\hline Q33 & Saya perlu pelatihan tentang pembelajaran online. \\
\hline Q34 & Teman sekelas saya perlu pelatihan tentang pembelajaran online. \\
\hline
\end{tabular}

Tabel 2. menunjukkan butir soal yang disajikan pada penelitian kesiapan pembelajaran online. Setiap butir soal disusun untuk mengukur aspek kesiapan mahasiswa dalam pembelajaran online sehingga didapatkan seberapa siap mahasiswa memulai proses pembelajaran online.

\section{Responden Penelitian}

Kuisioner pengukuran kesiapan pembelajaran online berisi 34 butir soal yang diukur dengan pilihan biner. Mahasiswa melaporkan tanggapan mereka pada 38 item kuisioner pengukuran kesiapan pembelajaran online dengan mengacu pada pilihan "Yes" dan "No". Responden saat ini adalah mahasiswa online yang terdaftar di dua perguruan tinggi di Malang, Jawa Timur, Indonesia. Sebanyak 500 kuisioner dibagikan melalui google form kepada mahasiswa, dan mendapatkan tanggapan sebesar $90 \%$ atau 450 responden dimana masing-masing responden memberikan tanggapan tentang kesiapan pembelajaran online. Variabel demografis meliputi gender dan jurusan program studi. Responden perempuan memiliki jumlah yang lebih banyak (72.89\%) yaitu 328 responden, dibandingkan dengan responden laki-laki (27.11\%) yaitu 122 responden, seperti yang ditunjukkan pada Tabel 3.

Tabel 3 Distribusi responden penelitian

\begin{tabular}{lll}
\hline \multicolumn{1}{c}{ Jenis Kelamin } & Frekuensi & Persentase \\
\hline Laki-Laki & 122 & $27.11 \%$ \\
\hline Perempuan & 328 & $72.89 \%$ \\
\hline Total & 450 & $100.00 \%$ \\
\hline
\end{tabular}

Responden yang terlibat pada penelitian ini terdiri dari beberapa program studi yaitu Hukum Keluarga Islam, Manajemen Bisnis Industri, Manajemen Broadcasting, Pendidikan Agama Islam, Pendidikan Guru Madrasah Ibtidaiyah, Pendidikan Islam Anak Usia Dini dan Teknik Informatika. Responden dari program studi Hukum Keluarga Islam berjumlah sebanyak 44 responden $(9,78 \%$, 20 responden laki-laki, 24 responden perempuan), responden dari program studi Manajemen Bisnis Industri berjumlah sebanyak 59 responden $(13,11 \%, 12$ responden laki-laki, 47 responden perempuan), responden dari program studi Manajemen Broadcasting berjumlah sebanyak 38 responden $(8,44 \%, 23$ responden laki-laki, 15 responden perempuan), responden dari program studi 
Pendidikan Agama Islam sebanyak 114 responden $(25,33 \%, 27$ responden laki-laki, 87 responden perempuan), responden dari prodi Pendidikan Guru Madrasah Ibtidaiyah sebanyak 124 responden $(27,56 \%, 5$ responden laki-laki, 119 responden perempuan), responden dari program studi Pendidikan Islam Anak Usia Dini sebanyak 27 responden $(6 \%, 27$ responden perempuan), dan responden dari program studi Teknik Informatika sebanyak 44 responden $(9,78 \%, 35$ responden laki-laki, 9 responden perempuan), sebagaimana ditunjukkan pada Tabel 4.

Tabel 4. Distribusi responden per program studi

\begin{tabular}{lcccc}
\hline \multicolumn{1}{c}{\begin{tabular}{c} 
Program \\
\multicolumn{1}{c}{ Studi }
\end{tabular}} & \multirow{2}{*}{$\%$} & \multicolumn{3}{c}{ JK } \\
\cline { 4 - 5 } $\begin{array}{l}\text { Kukum } \\
\text { Keluarga } \\
\text { Islam }\end{array}$ & 44 & 9.78 & 20 & 24 \\
\hline $\begin{array}{l}\text { Manajemen } \\
\text { Bisnis } \\
\text { Industri }\end{array}$ & 59 & 13.11 & 12 & 47 \\
\hline $\begin{array}{l}\text { Manajemen } \\
\text { Broadcasting }\end{array}$ & 38 & 8.44 & 23 & 15 \\
\hline $\begin{array}{l}\text { Pendidikan } \\
\text { Agama Islam }\end{array}$ & 114 & 25.33 & 27 & 87 \\
\hline $\begin{array}{l}\text { Pendidikan } \\
\text { Guru }\end{array}$ & 124 & 27.56 & 5 & 119 \\
$\begin{array}{l}\text { Madrasah } \\
\text { Ibtidaiyah }\end{array}$ & & & & \\
\hline $\begin{array}{l}\text { Pendidikan } \\
\text { Islam Anak }\end{array}$ & 27 & 6.00 & & 27 \\
Usia Dini & & & & \\
\hline $\begin{array}{l}\text { Teknik } \\
\text { Informatika }\end{array}$ & 44 & 9.78 & 35 & 9 \\
\hline $\begin{array}{l}\text { Total } \\
\text { Keterangan: Jenis Kelamin (JK); Laki-Laki } \\
\text { (LK); Perempuan (P) }\end{array}$ & & & \\
\hline
\end{tabular}

\section{HASIL DAN PEMBAHASAN}

Pengukuran dan tahap validitas kesiapan pembelajaran online melalui tiga tahap yaitu pengukuran reliabilitas instrumen, pengukuran validitas instrumen dan visualisasi data demografis terhadap kesiapan pembelajaran online. Proses pengukuran reliabilitas perlu dilakukan karena proses ini tidak dapat dipisahkan pada tahapan proses validasi sebuah sekala pengukuran / intrumen. Analisis tanggapan mahasiswa secara umum menanggapi setiap butir soal berdasarkan persepsi mahasiswa dalam konteks pendidikan untuk menghadapi pembelajaran online. Instrumen pengukuran menambahkan petunjuk pengisian butir soal, "Silahkan menjawab seluruh pertanyaan berdasarkan pengalaman Anda sebagai mahasiswa untuk menghadapi pembelajaran online". Pada proses pengumpulan data kesiapan pembelajaran online diperoleh sebanyak 450 mahasiswa memberikan tanggapan seperti yang ditunjukkan pada Tabel 5 .

Tabel 5. Tanggapan instrument pengukuran kesiapan pembelajaran online

\begin{tabular}{|c|c|c|c|}
\hline \multicolumn{4}{|c|}{ Case Processing Summary } \\
\hline & & $\mathrm{N}$ & $\%$ \\
\hline \multirow[t]{3}{*}{ Cases } & Valid & 450 & 100.0 \\
\hline & Excluded $^{\mathrm{a}}$ & 0 & .0 \\
\hline & Total & 450 & 100.0 \\
\hline
\end{tabular}

Tabel 5 menunjukkan bahwa jumlah tanggapan keseluruhan mahasiswa terdapat pengukuran kesiapan pembelajaran yang diberikan.

\section{Reliabilitas intrumen pengukuran kesiapan pembelajaran online}

Tahap reliabilitas bertujuan untuk mengetahui keandalan alat ukur dipergunakan pada kesiapan pembelajaran online. Penelitian menggunakan teknik corrected item-total correlation yang bertujuan untuk mengukur kesesuaian butir dengan kesesuaikan skala secara keseluruhan. Dimana semakin tinggi korelasi maka alat ukur atau instrumen memiliki tingkat konsistensi yang baik. Relibilitas instrument dapat dilihat pada nilai Cronbach's Alpha yang dihasilkan teknik corrected item-total correlation seperti pada Tabel 6 . 
Tabel 6. Statistik reliabilitas $(\mathrm{n}=450)$

\begin{tabular}{lll}
\hline \multicolumn{3}{l}{ Reliability Statistics } \\
\hline Cronbach's & $\mathrm{N}$ & of \\
Alpha & Items & \\
\hline .849 & 34 & \\
\hline
\end{tabular}

Tabel 6 menunjukkan tingkat reliabilitas butir terhadap keseluruhan variabel kesiapan pembelajaran online. Berdasarkan hasil pengukuran reliabilitas, memperoleh nilai konsisten internal berupa Cronbach's Alpha sebesar 0,849. Jika nilai Cronbach's Alpha > 0,60 maka dapat dianggap bahwa alat ukur memiliki konsisten internal yang dapat diterima atau reliabel (Brace, Kemp, \& Snelgar, 2021; Grove, Burns, \& Gray, 2013). Nilai Cronbach's Alpha $0,849>0,60$ memperoleh kesimpulan bahwa variabel kesiapan pembelajaran online secara keseluruhan adalah reliabel.

\section{Validasi Intrumen pengukuran kesiapan pembelajaran online}

Kami melakukan proses validasi terhadap survei kesiapan pembelajaran online dengan uji validitas corrected itemtotal correlation dalam rangka mengevaluasi apakah nilai survei mewakili kontruksi teoritis yang telah diidentifikasi sebelumnya. Berdasarkan uji validitas kesiapan pembelajaran online maka diperoleh nilai corrected item-total correlation yang biasanya disebut $\mathrm{r}_{\text {hitung. }}$ Proses pengambilan keputusan dapat mengacu ketentuan sebagai berikut:

1. Apabila dalam perhitungan diperoleh $r_{\text {hitung }}>r_{\text {tabel }}$ yang dimiliki product moment maka butir soal dapat dinyatakan valid.

2. Apabila dalam perhitungan diperoleh $\mathrm{r}_{\text {hitung }}<\mathrm{r}_{\text {tabel }}$ yang dimiliki product moment maka butir soal dapat dinyatakan tidak valid.

Berdasarkan acuan tersebut maka proses selanjutnya adalah mencari nilai $r_{\text {tabel }}$ yang berasal dari nilai $r$ tabel statistik (nilai degree of freedom $(d f)$ ). Perhitungan nilai $\mathrm{df}$ tergantung dari nilai $\mathrm{n}$, dimana $\mathrm{n}$ adalah jumlah responden penelitian. Penelitian ini melibatkan responden (n) sebanyak 450 mahasiswa (dapat dilihat pada Tabel 3), sehingga nilai $\mathrm{df}=\mathrm{n}-2$ mendapatkan $\mathrm{df}=$ $450-2=448$. Distribusi nilai $\mathrm{r}_{\text {tabel }}$ product moment pada $\mathrm{n}=450$ (signifikansi $5 \%$ ) sebesar 0,09265916. Nilai $\mathrm{r}_{\text {tabel }}$ kemudian dibandingkan dengan nilai $r_{\text {hitung }}$ yang telah diperoleh, seperti yang ditunjukkan pada Tabel 7.

Tabel 7. Corrected item-total correlation untuk kesiapan pembelajaran online $(n=450)$

\begin{tabular}{|c|c|c|c|c|c|c|c|c|}
\hline & & \multirow[b]{2}{*}{$\begin{array}{c}\text { Scale } \\
\text { Mean if } \\
\text { Item } \\
\text { Deleted }\end{array}$} & \multirow[b]{2}{*}{$\begin{array}{c}\text { Scale } \\
\text { Variance } \\
\text { if Item } \\
\text { Deleted }\end{array}$} & \multirow{2}{*}{\multicolumn{2}{|c|}{$\begin{array}{l}\text { Cronbach's } \\
\text { Alpha if } \\
\text { Item } \\
\text { Deleted } \\
(\alpha)\end{array}$}} & \multirow[b]{2}{*}{$r_{\text {hitung }} \mathrm{VS} \mathrm{r}_{\text {tabel }}$} & \multirow[b]{2}{*}{$\bar{X}$} & \multirow[b]{2}{*}{ SD } \\
\hline & & & & & & & & \\
\hline \multirow{6}{*}{$\begin{array}{c}\text { Ketersediaan } \\
\text { Teknologi }\end{array}$} & Q1 & 42,74 & 31,703 & 0,214 & 0,848 & $0,214>0,093$ & 1,09 & 0,282 \\
\hline & Q2 & 42,7067 & 31,54 & 0,223 & 0,848 & $0,223>0,093$ & 1,12 & 0,325 \\
\hline & Q3 & 42,26 & 30,179 & 0,373 & 0,845 & $0,373>0,093$ & 1,57 & 0,496 \\
\hline & Q4 & 42,2133 & 30,213 & 0,375 & 0,845 & $0,375>0,093$ & 1,61 & 0,488 \\
\hline & Q5 & 42,38 & 30,285 & 0,352 & 0,845 & $0,352>0,093$ & 1,45 & 0,498 \\
\hline & Q6 & 42,3844 & 30,219 & 0,365 & 0,845 & $0,365>0,093$ & 1,44 & 0,497 \\
\hline \multirow{4}{*}{$\begin{array}{c}\text { Tingkat } \\
\text { Penggunaan } \\
\text { Teknologi }\end{array}$} & Q7 & 42,7756 & 31,849 & 0,226 & 0,848 & $0,226>0,093$ & 1,05 & 0,220 \\
\hline & Q8 & 42,1622 & 30,555 & 0,322 & 0,846 & $0,322>0,093$ & 1,66 & 0,473 \\
\hline & Q9 & 42,0956 & 30,813 & 0,294 & 0,847 & $0,294>0,093$ & 1,73 & 0,444 \\
\hline & Q10 & 42,6467 & 31,369 & 0,219 & 0,848 & $0,219>0,093$ & 1,18 & 0,385 \\
\hline
\end{tabular}




\begin{tabular}{|c|c|c|c|c|c|c|c|c|}
\hline & & & & & Cronbach's & & & \\
\hline & & $\begin{array}{l}\text { Mean if } \\
\text { Item } \\
\text { Deleted }\end{array}$ & $\begin{array}{l}\text { Scale } \\
\text { Variance } \\
\text { if Item } \\
\text { Deleted }\end{array}$ & $\begin{array}{l}\text { Corrected } \\
\text { Item-Total } \\
\text { Correlation }\end{array}$ & $\begin{array}{l}\text { Alpha if } \\
\text { Item } \\
\text { Deleted } \\
(\alpha)\end{array}$ & $r_{\text {hitung }}$ VS $r_{\text {tabel }}$ & $\bar{X}$ & SD \\
\hline & Q11 & 42,7889 & 32,015 & 0,189 & 0,849 & $0,189>0,093$ & 1,04 & 0,191 \\
\hline & Q12 & 42,6333 & 31,351 & 0,215 & 0,849 & $0,215>0,093$ & 1,19 & 0,395 \\
\hline & Q13 & 42,78 & 32,096 & 0,133 & 0,849 & $0,133>0,093$ & 1,05 & 0,211 \\
\hline \multirow{12}{*}{$\begin{array}{c}\text { Kepercayaan } \\
\text { Diri }\end{array}$} & Q14 & 42,5956 & 30,611 & 0,358 & 0,845 & $0,358>0,093$ & 1,23 & 0,422 \\
\hline & Q15 & 42,5089 & 30,326 & 0,373 & 0,845 & $0,373>0,093$ & 1,32 & 0,466 \\
\hline & Q16 & 42,7067 & 31,179 & 0,323 & 0,846 & $0,323>0,093$ & 1,12 & 0,325 \\
\hline & Q17 & 42,7867 & 31,888 & 0,241 & 0,848 & $0,241>0,093$ & 1,04 & 0,196 \\
\hline & Q18 & 42,7556 & 31,593 & 0,277 & 0,847 & $0,277>0,093$ & 1,07 & 0,257 \\
\hline & Q19 & 42,3822 & 30,263 & 0,356 & 0,845 & $0,356>0,093$ & 1,44 & 0,497 \\
\hline & Q20 & 42,6667 & 31,114 & 0,296 & 0,847 & $0,296>0,093$ & 1,16 & 0,367 \\
\hline & Q21 & 42,5533 & 30,435 & 0,371 & 0,845 & $0,371>0,093$ & 1,27 & 0,446 \\
\hline & Q22 & 42,46 & 30,213 & 0,38 & 0,844 & $0,38>0,093$ & 1,37 & 0,482 \\
\hline & Q23 & 42,6222 & 30,752 & 0,345 & 0,845 & $0,345>0,093$ & 1,20 & 0,404 \\
\hline & Q24 & 42,5978 & 29,938 & 0,509 & 0,841 & $0,509>0,093$ & 1,23 & 0,421 \\
\hline & Q25 & 42,5067 & 29,645 & 0,511 & 0,84 & $0,511>0,093$ & 1,32 & 0,467 \\
\hline \multirow{7}{*}{$\begin{array}{c}\text { Penerimaan } \\
\text { terhadap } \\
\text { Teknologi }\end{array}$} & Q26 & 42,5467 & 29,732 & 0,515 & 0,84 & $0,515>0,093$ & 1,28 & 0,449 \\
\hline & Q27 & 42,4933 & 29,734 & 0,486 & 0,841 & $0,486>0,093$ & 1,33 & 0,472 \\
\hline & Q28 & 42,4489 & 29,513 & 0,514 & 0,84 & $0,514>0,093$ & 1,38 & 0,485 \\
\hline & Q29 & 42,2289 & 29,687 & 0,473 & 0,841 & $0,473>0,093$ & 1,60 & 0,491 \\
\hline & Q30 & 42,3 & 29,716 & 0,458 & 0,842 & $0,458>0,093$ & 1,53 & 0,500 \\
\hline & Q31 & 42,7311 & 31,043 & 0,406 & 0,844 & $0,406>0,093$ & 1,10 & 0,294 \\
\hline & Q32 & 42,4444 & 29,423 & 0,531 & 0,839 & $0,531>0,093$ & 1,38 & 0,486 \\
\hline \multirow{2}{*}{$\begin{array}{l}\text { Kebutuhan } \\
\text { Pelatihan } \\
\text { Penggunaan } \\
\text { Pembelajaran } \\
\text { Online }\end{array}$} & Q33 & 42,68 & 31,884 & 0,113 & 0,851 & $0,113>0,093$ & 1,15 & 0,354 \\
\hline & Q34 & 42,6978 & 31,548 & 0,212 & 0,848 & $0,212>0,093$ & 1,13 & 0,335 \\
\hline
\end{tabular}

Tabel 7 menunjukkan bahwa alat ukur kesiapan pembelajaran online memiliki reliabilitas dan validitas yang baik. Masing-masing 5 konstruks memiliki validitas dan reliabitas yang baik ditunjukkan pada kontruks "Ketersediaan Teknologi” (Q1-Q6), “Tingkat Penggunaan Teknologi" (Q7-Q13), "Kepercayaan Diri” (Q14-Q25), "Penerimaan terhadap Teknologi” (Q26-Q32) dan "Kebutuhan Pelatihan Penggunaan Pembelajaran Online" (Q33-Q34). Item pada instrument ini diambil berdasarkan 5 konstruks yang ditunjukkan pada Tabel 7. Konstruks ketersediaan teknologi mencakup pernyataan seperti Q1 $(\bar{x}=1,09 ; \mathrm{SD}=0,282)$ yaitu "Fasilitas perangkat kerasnya sudah cukup. (Misal Komputer, Laptop, Tablet, dan handphone)". Q2 ( $\bar{x}=1,12 ; \mathrm{SD}=0,325)$ yang menyatakan "Fasilitas perangkat lunaknya sudah cukup. (Misal Sistem Operasi windows, Aplikasi microsoft office (word, excel, powerpoint), dan aplikasi pendukung yang lain)" dimana pada item ini menunjukkan kebutuhan dasar terhadap kepemilikan perangkat keras yang didukung dengan perangkat lunak yang cukup memadai. Menurut Chai et al. (2013), pengetahuan terhadap bagaimana menggunakan perangkat keras dan perangkat lunak merupakan hal yang penting dalam proses pembelajaran. 
Penguasaan terhadap perangkat keras dapat mempengaruhi keterampilan mahasiswa dalam menggunakan perangkat tersebut dan lebih memahami kemampuan kinerja perangkat keras. Sedangkan penguasaan terhadap perangkat lunak dapat membantu dalam penyelesaian masalah dalam pembelajaran online. Skor nilai Cronbach's alpha yang diperoleh masing-masing item, Q1 dan Q2, sebesar 0.848. Pada pengukuran konstruks "Ketersediaan Teknologi" juga memuat pernyataan terkait kecepatan dan stabilitas internet yang digunakan selama proses pembelajaran online. Pernyataan terkait penggunaan internet mencakup pernyataan "Kecepatan akses internet memuaskan." (Q3; $\bar{x}=1,57$; $\mathrm{SD}=0,496)$ dan "Stabilitas akses internet memuaskan" (Q4; $\bar{x}=1,61 ; \mathrm{SD}=0,488)$ dimana masing-masing pada kedua item memiliki tingkat kevalidan (lihat Tabel 7) dan mendapatkan skor nilai Cronbach's alpha sebesar 0,845. Kualitas internet baik kecepatan dan stabilitasnya mempengaruhi proses pembelajaran yang memberikan kesempatan untuk belajar mengajar lebih baik. Akses internet yang lebih baik dapat memberikan peluang untuk mendapatkan informasi , sumber daya dan keterampilan baru lebih banyak pada era digital (Souter, 2017). Selanjutnya pada item Q5 danQ6, mahasiswa memberikan pernyataan untuk memiliki pada akses terhadap penggunaan komputer kapan pun dan akses internet kapanpun mereka ingin mengakses pembelajaran online. Item Q5 $(\bar{x}=1,45$; $\mathrm{SD}=0,498)$ dan $\mathrm{Q} 6(\bar{x}=1,44 ; \mathrm{SD}=0,497)$ mempunyai skor nilai Cronbach's alpha $(\alpha)$ sebesar 0,845. Skor nilai Cronbach's alpha yang dimiliki item Q1-Q6 memiliki skor nilai Cronbach's alpha atau koefisien alpha di atas 0, 7 sehingga keseluruhan item pada kontruks "Ketersediaan Teknologi" dapat dinyatakan reliabel atau konsisten (Brace et al., 2021).

Kontruks "Tingkat Penggunaan Teknologi” terdiri dari tujuh item (Q7-Q13) dimana pada bagian ini menyajikan terkait penggunaan berbagai perangkat lunak dan tool yang mendukung proses pembelajaran online. Item Q7 menyatakan mahasiswa telah terbiasa untuk menggunakan perangkat lunak seperti Microsoft office $(\bar{x}=1,05 ; \quad \mathrm{SD}=0,220) . \quad$ Penggunaan perangkat lunak ini mendapatkan skor nilai Cronbach's alpha $(\alpha)$ sebesar 0,848 . Sedangkan pada item Q8 menyatakan bahwa mahasiswa memiliki kemampuan untuk menggunakan perangkat lunak yang lain $(\bar{x}=1,66 ; \mathrm{SD}=0,473)$, dengan skor nilai Cronbach's alpha $(\alpha)$ sebesar 0,846 . Kedua item ini, Q7 dan Q8 memiliki hubungan yang erat terkait keterampilan mahasiswa dalam mempergunakan perangkat lunak sebagaimana pernyataan dari Siddiquah \& Salim (2017), mahasiswa yang memiliki kemampuan dalam mengoperasikan perangkat lunak seperti Microsoft office dan perangkat lunak yang lain lebih dapat menyebabkan pemikiran yang inovatif, kognitif yang lebih baik dan produktifitas yang tinggi dalam proses pembelajaran. Kemampuan mahasiswa dalam penguasaan terhadap perangkat lunak didukung oleh kemampuan mereka dalam menggunakan web 2.0 (Q9; $\bar{x}=1,73 ; \mathrm{SD}=0,444 ; \alpha=0,847$ ), layanan hosting $(\mathrm{Q} 10 ; \bar{x}=1,18 ; \mathrm{SD}=0,385$; $\alpha=0,848)$, sistem manajemen pembelajaran (Q11; $\bar{x}=1,04 ; \mathrm{SD}=0,191 ; \alpha=0,849)$, forum online (Q12; $\bar{x}=1,19 ; \mathrm{SD}=0,395 ; \alpha=0,849)$, dan teknologi seluler (Q13; $\bar{x}=1,05 ; \mathrm{SD}=$ $0,211 ; \alpha=0,849)$. Penguasaan mahasiswa terhadap perangkat lunak, aplikasi web dan sistem manajemen pembelajaran dapat membantu mahasiswa untuk lebih mudah dapat menghadapi pembelajaran online. Somayeh et al. (2016) menganggap bahwa penguasaan diri dalam keterampilan menggunakan perangkat lunak dan teknologi mengarah pada peningkatan kemampuan belajar pada mahasiswa Selain itu, mahasiswa mampu berkembang dalam proses pembelajaran dengan memiliki keterampilan dalam penggunaan teknologi (Sadik, 2008). Skor item Cronbach's alpha $(\alpha)$ Q7-Q13 secara keseluruhan 
memperoleh skor nilai $\alpha$ lebih besar dari 0,7 sehingga dapat dinyatakan bahwa kontruks ““Tingkat Penggunaan Teknologi” memenuhi syarat reliabel.

Kesiapan pembelajaran online memerlukan aspek kepercayaan diri terhadap penggunaan teknologi, dimana pada penelitian ini kepercayaan diri yang dibutuhkan tidak hanya pada penggunaan teknologi tetapi juga penggunaan pada pembelajaran online. Item pertanyaan pada kontruks "Kepercayaan Diri" (Q14-Q25) yang diberikan kepada mahasiswa meliputi apakah mahasiswa memiliki informasi yang awal terhadap pembelajaran online $(\mathrm{Q} 14$; $\bar{x}=1,23 ; \mathrm{SD}=0,422 ; \alpha=0,845)$, dan apakah mahasiswa memiliki kemampuan awal untuk mengoperasikan komputer (Q15; $\bar{x}=1,32 ; \mathrm{SD}=0,466 ; \alpha=0,845)$. Sedangkan kemampuan untuk menggunakan perangkat lunak dalam proses pembelajaran online (Q16; $\quad \bar{x}=1,12 ; \quad \mathrm{SD}=0,325 ; \quad \alpha=0,846$ ), penggunaan browser (Q17; $\bar{x}=1,04 ; \mathrm{SD}=$ $0,196 ; \quad \alpha=0,848), \quad$ keterampilan mempergunakan mesin pencari (Q18; $\bar{x}=1,07 ; \mathrm{SD}=0,196 ; \alpha=0,848)$ dan mencoba memecahkan masalah terkait penggunaan perangkat komputer $(\mathrm{Q} 19 ; \bar{x}=1,44 ; \mathrm{SD}=$ $0,497 ; \alpha=0,845)$ menjadi perhatian dalam pembahasan selanjutnya. Pembahasan ini membahas terkait adanya kemampuan dan infromasi awal yang perlu dimiliki oleh mahasiswa sebelum mereka menghadapi pembelajaran online, sebagai penelitian yang dilakukan oleh Ferreira et al. (2018) yang menyatakan bahwa mahasiswa mengakses informasi dan sumber daya untuk mengembangkan kegiatan kolaboratif dan menyelesaikan masalah dalam pembelajaran online. Sebuah paradigma kompleksitas baru dimana mahasiswa tidak sekedar menghafal informasi tetapi mahasiswa mampu untuk mengelola informasi yang tersedia dan mengubahnya menjadi pengetahuan yang relevan. Mahasiswa perlu untuk mempertimbangkan keterampilan teknis dan pengetahuan tentang komputer dasar dan keterampilan internet saat berpartisipasi dalam pembelajaran online (Instructional Technology \& Distance Education Services, 2021). Hasil penelitian dari Instructional Technology \& Distance Education Services (2021) mendukung penemuan ini yang dijabarkan pula pada item pertanyaan Q20 yang menyatakan kemampuan mahasiswa untuk menggunakan proses manajemen file $(\bar{x}=1,16 ; \quad \mathrm{SD}=0,367 ; \quad \alpha=0,847) \quad$ dan menyelesaikan tugas kuliah dengan menggunakan tools yang tersedia pada pembelajaran online $(\mathrm{Q} 21 ; \bar{x}=1,27 ; \mathrm{SD}=$ $0,446 ; \quad \alpha=0,845)$. Mahasiswa memiliki cukup waktu dalam menyelesaikan tugas kuliah dengan menggunakan teknologi (Q22; $\bar{x}=1,37 ; \quad \mathrm{SD}=\quad 0,482 ; \quad \alpha=0,844)$ memberikan kesempatan untuk mengembangkan kemampuannya dalam penyelesaian masalah. Selain itu kemampuan tersebut dapat berdampak dalam penggunaan pembelajaran online $(\mathrm{Q} 23 ; \bar{x}=1,20 ; \quad \mathrm{SD}=\quad 0,404 ; \quad \alpha=0,845)$. Kemampuan dan keterampilan yang dimiliki dapat mengakibatkan kepercayaan mahasiswa pada pembelajaran online (Q24) dan kesiapan mahasiswa dalam pembelajaran online (Q25). Hal tersebut sependapat dengan pernyataan dari Kamdi (2017), seseorang yang memiki tingkat kepercayaan yang tinggi diyakini dapat menerapkan kompetensi jika menghadapi situasi lingkungan belajar yang baru dan dapat bekerja sama dengan orang lain. Mahasiswa yang memiliki kepercayaan diri yang tinggi memungkinkan mereka untuk membawa teknologi dalam kelas (Kadry \& El-Hami, 2016).

Pembahasan selanjutnya adalah terkait dengan penerimaan teknologi, sebagaimana dengan penelitian yang dilakukan oleh Yang \& Kwok (2017) bahwa penerimaan teknologi dapat mendukung terhadap persepsi kegunaan dan kemudahan menggunakan teknologi yang berkorelasi positif dengan sikap dalam penggunaan teknologi. Pada penelitian ini 
konstruk "penerimaan teknologi" membahas bagaimana mahasiswa menggunakan pembelajaran online untuk mendukung proses pembelajaran. Oleh sebab itu maka tingkat penerimaan teknologi menjadi hal yang penting dalam proses penggunaan pembelajaran online. Mahasiswa menyatakan bahwa mereka memiliki kesiapan untuk mengikuti pembelajaran online (Q26) memperoleh means $(\bar{x})$ sebesar 1,28 dengan standar deviasi (SD) 0,$449 ; \alpha=0,84$. Mahasiswa juga memiliki kepercayaan pada penggunaan pembelajaran online dimana mereka beranggapaan bahwa pembelajaran online dapat meningkatkan kualitas dalam belajar $\quad(\mathrm{Q} 27 ; \bar{x}=1,33 ; \quad \mathrm{SD}=\quad 0,449$; $\alpha=0,841$ ). Hal tersebut sependapat dengan yang dilakukan oleh Valencia-Vallejo, López-Vargas, \& Sanabria-Rodríguez (2016) dimana kepercayaan diri merupakan prediktor keberhasilan kinerja mahasiswa dalam lingkungan komputasi, dimana seperti yang diketahui bahwa lingkungan komputasi adalah salah satu bagian dari pembelajaran online. Pembahasan berikutnya adalah item Q28 - Q31. Mahasiswa memiliki kepercayaan bahwa pembelajaran online dapat meningkatkan produktivitas mereka dalam belajar (Q28; $\bar{x}=1,38 ; \mathrm{SD}=0,485 ; \alpha=0,84$ ). Selain itu mahasiswa mempercayai bahwa pembelajaran online lebih efektif daripada pembelajaran konvensional (Q29; $\bar{x}=1,60$; $\mathrm{SD}=0,491 ; \alpha=0,841)$. Pernyataan tersebut sependapat dengan penelitian yang dilakukan oleh Benta, Bologa, Dzitac, \& Dzitac (2015) menyatakan bahwa penggunaan pembelajaran online terbukti menjadi suatu langkah yang besar dalam menanggapi kebutuhan pembelajaran pada pembelejaran yang berorientasi pada peserta didik, dalam hal ini adalah mahasiswa. Namun, keberhasilan dalam pembelajaran online dibandingkan pembelajaran konvensional perlu dievaluasi pula apakah pembelajaran online yang telah dilakukan secara mandiri atau menggunakan bantuan dari instruktur. Menurut Noesgaard, Ørngreen, \& Foundation (2015), tingkat keberhasilan pembelajaran online yang terkait dengan efektivitas pembelajaran dapat terjadi jika pembelajaran online dipimpin oleh instruktur daripada pembelajaran online mandiri. Oleh sebab itu maka penelitian ini dapat menjadi sebuah pertimbangan untuk mengukur keefektifan pembelajaran online. Hal penelitian tersebut berhubungan dengan pernyataan pada item Q30 yang menyatakan bahwa mahasiswa memiliki kepercayaan terhadap interaksi yang dilakukan oleh mahasiswa dan instruktur dalam pembelajaran online $(\bar{x}=1,53 ; \mathrm{SD}=$ $0,500 ; \alpha=0,842)$. Selain itu, mahasiswa memiliki kepercayaan terhadap manfaat pembelajaran online $(\mathrm{Q} 31 ; \bar{x}=1,10 ; \mathrm{SD}=$ $0,500 ; \quad \alpha=0,844) \quad$ sehingga mereka mendukung pembelajaran online untuk diimplementasikan dalam proses pembelajaran $(\mathrm{Q} 32 ; \bar{x}=1,38 ; \mathrm{SD}=0,486$; $\alpha=0,839$ ). Keseluruhan item (Q26-Q32) secara keseluruhan memperoleh skor nilai $\alpha$ lebih besar dari 0,7 sehingga dapat dinyatakan bahwa kontruks "Tingkat Penggunaan Teknologi" memenuhi syarat reliabel. Sedangkan pada konstruks "Kebutuhan Pelatihan Penggunaan Pembelajaran Online", mahasiswa memiliki kebutuhan terhadap pelatihan untuk menggunakan pembelajaran online (Q33; $\bar{x}=1,15 ; \quad \mathrm{SD}=0,354 ; \quad \alpha=0,851) \quad$ dan mahasiswa dalam kelas yang sama juga memiliki kebutuhan terhadap pelatihan penggunaan pembelajaran online (Q34; $\bar{x}=1,13 ; \quad \mathrm{SD}=0,335 ; \quad \alpha=0,848) . \quad$ Kedua pernyataan ini sependapat dengan penelitian yang dilakukan oleh FitzPatrick (2012) yang menyatakan bahwa kurangnya pelatihan dan kecakapan terhadap penggunaan teknologi yang disediakan dapat menghambat keefektifan pelaksanaan pembelajaran online. Berdasarkan hal tersebut maka pertimbangan terkait kebutuhan pelatihan perlu untuk dibahas lebih lanjut. 
Proses integrasi ICT pada pembelajaran tidak hanya melibatkan perangkat keras dan perangkat lunak tetapi juga bagaimana seorang mahasiswa mengadopsi beradaptasi pada peran dan perilaku baru dalam proses pembelajaran online, oleh sebab itu maka kesiapan terhadap pembelajaran online perlu untuk diperhatikan (Turugare \& Rudhumbu, 2020). Kemampuan mahasiswa untuk mempergunakan pembelajaran online memiliki keefektifan dalam proses pembelajaran (Rasouli et al., 2016). Kesiapan mahasiswa untuk menghadapi pembelajaran online pada penelitian ini terdiri dari lima aspek yaitu Ketersediaan Teknologi $(\bar{x}=1,38)$; Tingkat Penggunaan Teknologi $\quad(\bar{x}=1,18)$; Kepercayaan Diri $(\bar{x}=1,23)$, Penerimaan terhadap Teknologi $(\bar{x}=1,37) \quad$ dan Kebutuhan Pelatihan penggunaan pembelajaran online $(\bar{x}=1,14)$ seperti yang ditunjukkan pada Gambar 2.

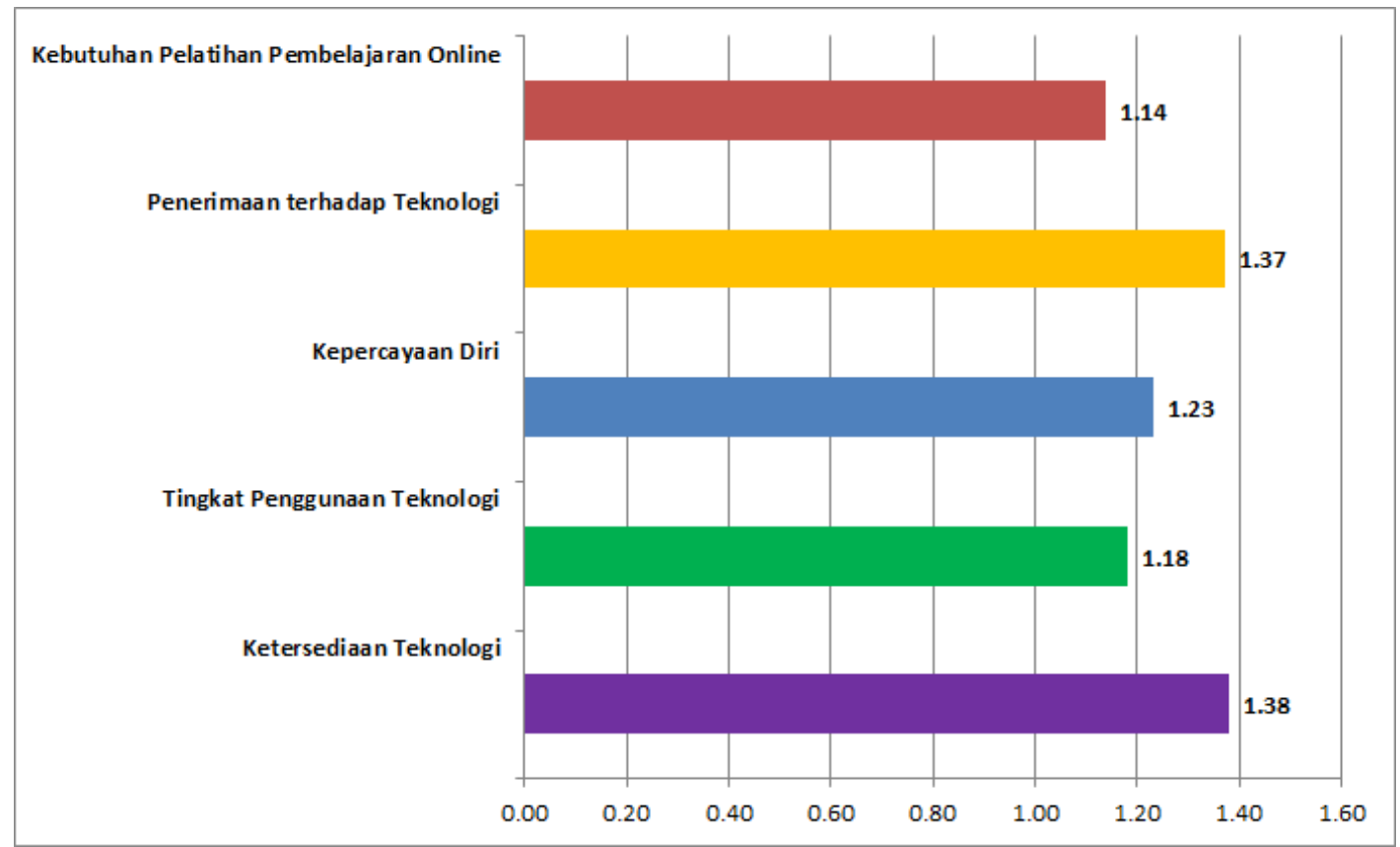

Gambar 2. Rata-rata aspek kesiapan pembelajaran online berdasarkan item skala pengukuran

Gambar 2 menunjukkan sebagian besar mahasiswa menyatakan bahwa aspek ketersediaan teknologi menjadi perhatian utama dalam kesiapan pembelajaran online, kemudian diikuti dengan dengan aspek penerimaan terhadap teknologi. Kesiapan mahasiswa terhadap teknologi mempengaruhi partisipasi mereka dalam kelas pembelajaran online dimana mahasiswa yang memiliki kesiapan teknologi yang rendah cenderung untuk mengkombinasikan antara pembelajaan online dengan pembelajaran tatap muka (Rhee, Verma, Plaschka, \& Kickul, 2007). Sedangkan pada aspek selanjutnya seperti kepercayaan diri, tingkat penggunaan teknologi dan kebutuhan terkait pelatihan memiliki nilai rata-rata dibawah ketersediaan teknologi. Hal ini disebabkan karena teknologi menjadi perangkat pendukung utama dalam proses pembelajaran. Menurut Martin \& Bolliger (2018), mahasiswa mengharapkan ketersediaan infrastruktur dan bantuan instruktur untuk membantu mereka dalam proses pembelajaran mereka dan menciptakan sebuah pengalaman pembelajaran yang bermakna.

\section{Data demografis terhadap kesiapan pembelajaran online}

Data yang berasal dari dua variabel demografis terdiri dari jenis kelamin dan program studi seperti yang ditunjukkan 
pada Tabel 8. Variabel demografis dikumpulkan dari 122 responden laki-laki dan 328 responden perempuan. Mayoritas responden berasal dari program studi Pendidikan Guru Madrasah Ibtidaiyah sebanyak 124 responden (5 Laki-Laki, 119 Perempuan). Sedangkan program studi yang memiliki responden terendah adalah
Pendidikan Islam Anak Usia Dini dengan jumlah responden sebanyak 27 responden (27 Perempuan). Keberagaman jumlah responden yang terlibat pada penelitian ini bertujuan untuk mengukur apakah perbedaan demografis memberikan pengaruh pada kesiapan pembelajaran online

Tabel 8. Informasi demografis responden

\begin{tabular}{|c|c|c|c|c|c|c|c|}
\hline \multicolumn{2}{|r|}{ Faktor Demografis } & \multicolumn{6}{|c|}{$\begin{array}{c}\text { Rata-Rata }(\bar{x}) \text { per Aspek Kesiapan } \\
\text { Pembelajaran Online }\end{array}$} \\
\hline Jenis Kelamin & Program Studi & KT & TPT & $\mathrm{KD}$ & KPPO & PTT & $\mathrm{n}$ \\
\hline \multirow{6}{*}{ Laki-Laki } & Hukum Keluarga Islam & 0,36 & 0,75 & 0,61 & 0,9 & 0,37 & 20 \\
\hline & Manajemen Bisnis Industri & 0,78 & 0,87 & 0,92 & 1 & 0,93 & 12 \\
\hline & Manajemen Broadcasting & 0,67 & 0,87 & 0,83 & 0,8 & 0,58 & 23 \\
\hline & Pendidikan Agama Islam & 0,53 & 0,82 & 0,74 & 0,93 & 0,76 & 27 \\
\hline & Pendidikan Guru Madrasah Ibtidaiyah & 0,5 & 0,82 & 0,85 & 0,9 & 0,66 & 5 \\
\hline & Teknik Informatika & 0,66 & 0,86 & 0,95 & 0,77 & 0,76 & 35 \\
\hline \multicolumn{2}{|c|}{ Total Responden Laki-Laki } & 0,59 & 0,83 & 0,82 & 0,86 & 0,67 & 122 \\
\hline \multirow[t]{7}{*}{ Perempuan } & Hukum Keluarga Islam & 0,57 & 0,82 & 0,72 & 0,85 & 0,48 & 24 \\
\hline & Manajemen Bisnis Industri & 0,72 & 0,81 & 0,84 & 0,93 & 0,75 & 47 \\
\hline & Manajemen Broadcasting & 0,68 & 0,87 & 0,86 & 0,63 & 0,44 & 15 \\
\hline & Pendidikan Agama Islam & 0,65 & 0,81 & 0,67 & 0,92 & 0,61 & 87 \\
\hline & Pendidikan Guru Madrasah Ibtidaiyah & 0,62 & 0,82 & 0,76 & 0,83 & 0,58 & 119 \\
\hline & Pendidikan Islam Anak Usia Dini & 0,54 & 0,78 & 0,72 & 0,93 & 0,68 & 27 \\
\hline & Teknik Informatika & 0,69 & 0,87 & 1 & 0,67 & 0,79 & 9 \\
\hline \multicolumn{2}{|c|}{ Total Responden Perempuan } & 0,63 & 0,82 & 0,75 & 0,86 & 0,61 & 328 \\
\hline \multicolumn{2}{|c|}{ Grand Total } & 0,62 & 0,82 & 0,77 & 0,86 & 0,63 & 450 \\
\hline
\end{tabular}

Tabel 8 menunjukkan bahwa sebagian besar responden laki-laki pada program studi Manajemen Bisnis Industri memiliki rata-rata aspek ketersediaan teknologi $(\bar{x}=0,78)$. Begitu juga dengan responden perempuan program studi Manajemen Bisnis Industri memiliki tingkat rata-rata ketersediaan teknologi $(\bar{x}=0,72)$. Hasil penelitian tersebut sangat menarik karena meskipun jumlah koresponden program studi Manajemen Bisnis Industri $(\mathrm{n}=59)$ tidak sebanyak jumlah responden program studi yang lain tetapi mayoritas responden memiliki kesiapan terhadap teknologi. Menurut
Bakirtas \& Akkas (2017), terdapat hasil perbedaan yang signifikan antara faktor ketersediaan teknologi dengan program studi dan jenjang pendidikan mahasiswa pada program sarjana. Hasil penelitian tersebut menunjukkan pengaruh jenjang program studi dan pilihan program studi terhadap ketersediaan teknologi. Dalam penelitian yang lain menyatakan bahwa perbedaan jenis kelamin tidak memberikan pengaruh signifikan terhadap ketersediaan teknologi dimana ketersediaan teknologi lebih dipengaruhi oleh hubungan perilaku dan pengguaan teknologi secara actual (Tsourela \& Roumeliotis, 2015). Hasil 
penelitian ini secara keseluruhan responden perempuan memiliki nilai rata-rata ketersediaan teknologi yang lebih tinggi $(\bar{x}=0,63)$ dari pada nilai rata-rata ketersediaan teknologi pada responden laki- laki $(\bar{x}=0,59)$. Visualisasi hasil penelitian pada aspek ketersediaan teknologi dapat dilihat pada Gambar 3.

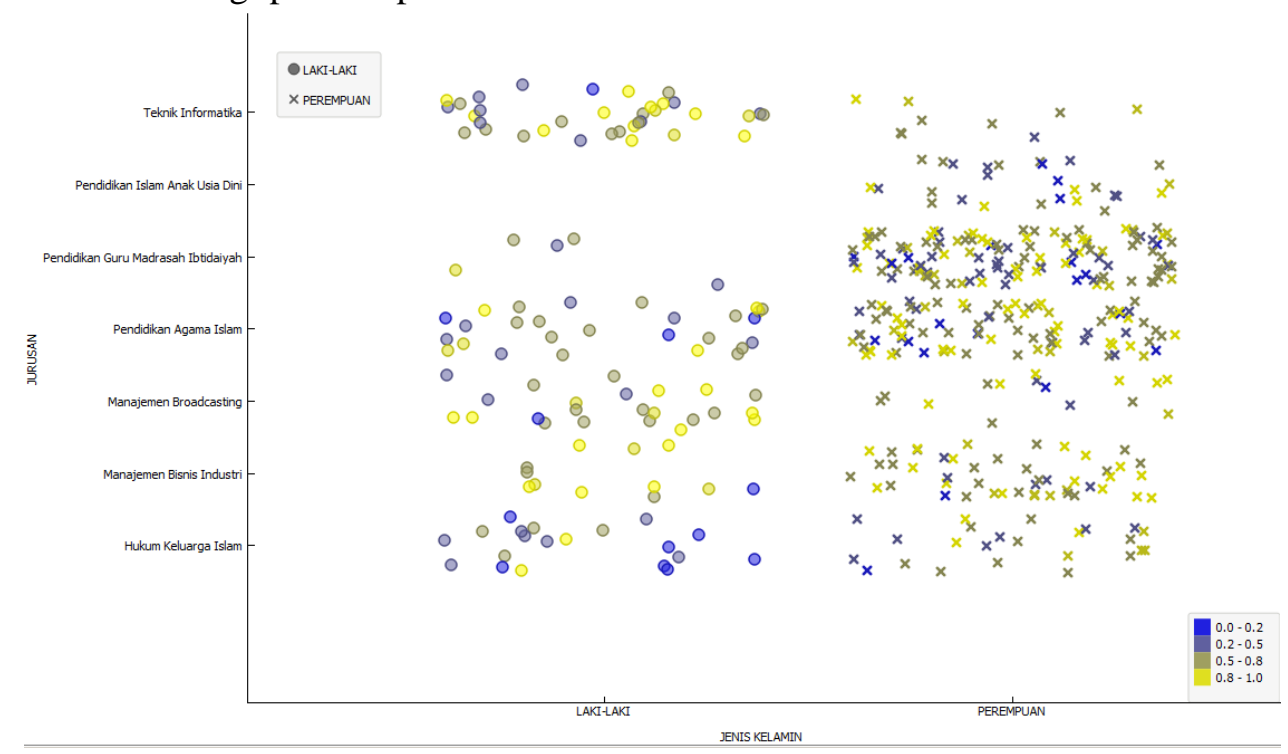

Gambar 3. Visualisasi data ketersediaan teknologi berdasarkan demografis

Aspek berikutnya adalah tingkat penggunaan teknologi dimana responden laki-laki memiliki nilai rata-rata yang hampir merata pada beberapa program studi seperti Manajemen Bisnis Industri $(\bar{x}=0,87), \quad$ Manajemen Broadcasting $(\bar{x}=0,87)$ dan Teknik Informatika $(\bar{x}=0,86)$. Hasil yang serupa pun diperoleh pada responden perempuan, dimana program studi memiliki nilai rata-rata yang hampir merata (lihat Tabel 8), Manajemen Broadcasting $(\bar{x}=0,87)$ dan Teknik Informatika $(\bar{x}=0,87)$. Secara keseluruhan responden laki-laki pada aspek tingkat penggunaan teknologi memiliki nilai ratarata yang lebih tinggi $(\bar{x}=0,83)$ jika dibandingkan dengan nilai rata-rata aspek penggunaan teknologi pada responden perempuan $(\bar{x}=0,82)$. Berdasarkan hasil penelitian diperoleh hasil bahwa gender tidak memberikan pengaruh yang signifikan terhadap aspek tingkat penggunaan teknologi. Hasil penelitian ini mendukung penelitian yang dilakukan oleh Cai, Fan, \& $\mathrm{Du}$ (2017) yang menyatakan bahwa terdapat perbedaan efek yang kecil pada jenis kelamin terhadap penggunaan teknologi meskipun responden laki-laki memiliki sikap menyukai teknologi daripada responden perempuan. Adapun visualisasi data tingkat penggunaan teknologi berdasarkan jenis kelamin dan program studi dapat dilihat pada Gambar 4. 


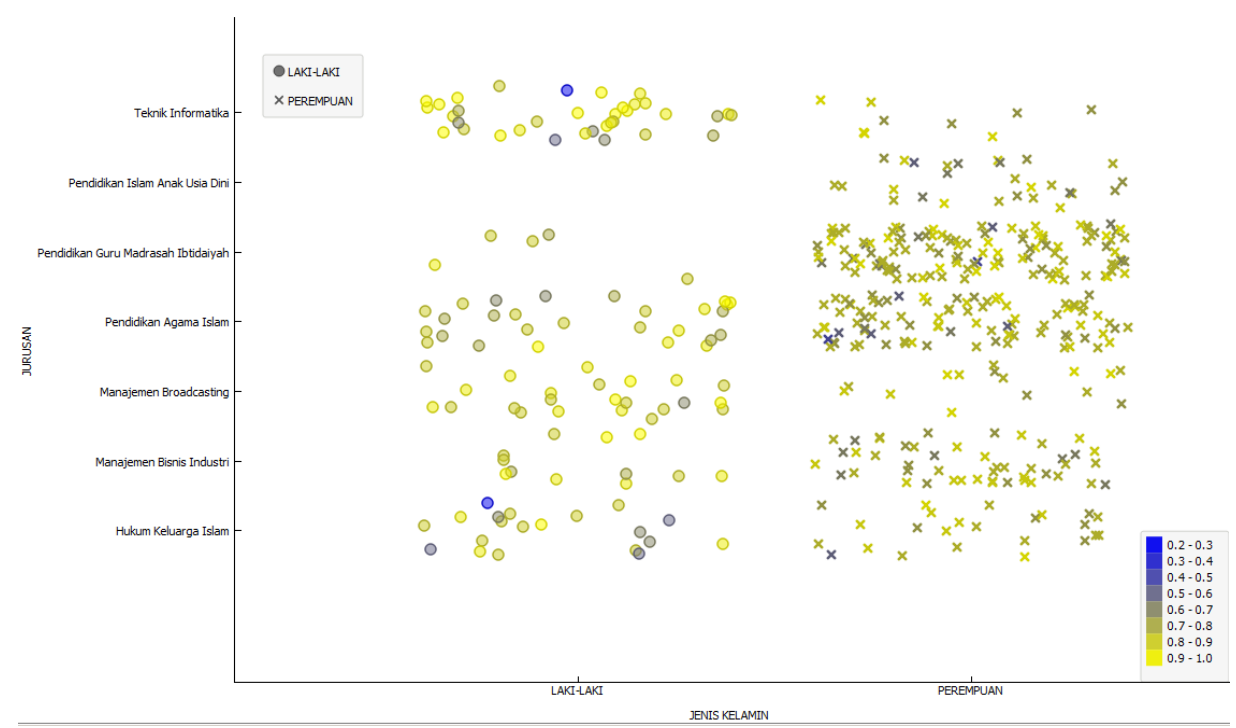

Gambar 4. Visualisasi data tingkat penggunaan teknologi berdasarkan demografis

Penelitian ini mendapatkan bahwa pada kepercayaan diri responden laki-laki memiliki tingkatan yang lebih tinggi $(\bar{x}=0,82)$ dari pada kecercayaan diri responden perempuan $(\bar{x}=0,75)$. Pada tingkatan program studi, responden lakilaki pada program studi Teknik Informatika memiliki nilai rata-rata kepercayaan diri yang tertinggi yang diikuti juga dengan responden perempuan memiliki nilai ratarata yang tinggi pula. Hal ini dapat disebabkan karena kepercayaan tinggi dapat tumbuh dari kemampuan awal yang dimiliki mahasiswa sebelum mengikuti pembelajaran online. Kepercayaan diri (efikasi diri) yang dimiliki oleh mahasiswa memberikan kontribusi yang positif terhadap kepuasan belajar (Kuo, Walker,
Belland, Schroder, \& Kuo, 2014). Pernyataan tersebut didukung pula dengan penelitian yang dilakukan oleh Martin, Stamper, \& Flowers (2020) yang menyatakan bahwa kepercayaan diri memiliki peran penting terhadap kinerja dan kesiapan dalam pembelajaran online. Pengaruh penggunaan komputer sebelum mengikuti pembelajaran online memberikan pengaruh positif terhadap kemandirian dalam pembelajaran online, dimana mereka memiliki kepercayaan diri dalam mengikuti proses pembelajaran (Simmering, Posey, \& Piccoli, 2009). Penyajian data penelitian pada aspek kepercayaan diri ditunjukkan pada Gambar 5.

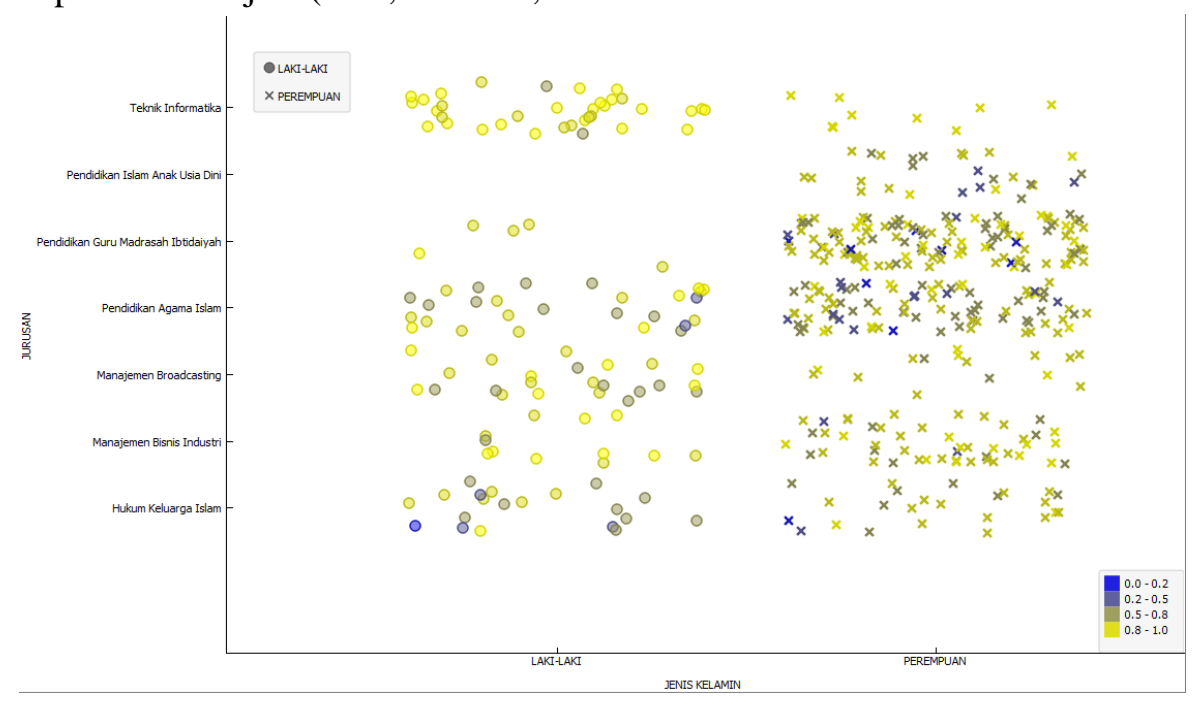


Gambar 5. Visualisasi data kepercayaan diri berdasarkan demografis

Dalam kesiapan pembelajaran online terdapat aspek yang perlu untuk dipertimbangkan pula yaitu aspek penerimaan teknologi. Aspek penerimaan teknologi pada responden laki-laki $(\bar{x}=0,67)$ memiliki nilai rata-rata yang lebih besar dibandingkan dengan aspek penerimaan teknologi pada respon perempuan $(\bar{x}=0,61)$. Sedangkan penerimaan teknologi apabila dijelaskan berdasarkan pendekatan program studi maka pada responden laki-laki pada program studi Manajemen Bisnis Industri mendapat nilai rata-rata tertinggi sebesar 0,93. Begitu pula dengan responden perempuan yang memperoleh nilai rata-rata tertinggi berasal dari program studi yang sama, sebesar 0,75. Berdasarkan hasil penelitian ini maka dapat dilihat bahwa terdapaat perbedaan pengaruh jenis kelamin terhadap penerimaan teknologi. Hasil penelitian ini merujuk pula dengan hasil penelitian yang dilakukan oleh PadillaMeléndez, Del Aguila-Obra, \& GarridoMoreno (2013), dimana perbedaan jenis kelamin mempengaruhi sikap terhadap teknologi dan niat untuk penggunaan teknologi. Sikap dan niat dalam penggunaan teknologi ini terkait dengan bagaimana mahasiswa memiliki keinginan dan ketertarikan dalam menggunakan teknologi. Adapun visualisasi aspek penerimaan teknologi dapat dilihat pada Gambar 6. Gambar 6 menunjukkan distribusi nilai rata-rata penerimaan teknologi jika dijelaskan berdasarkan perbedaan jenis kelamin.

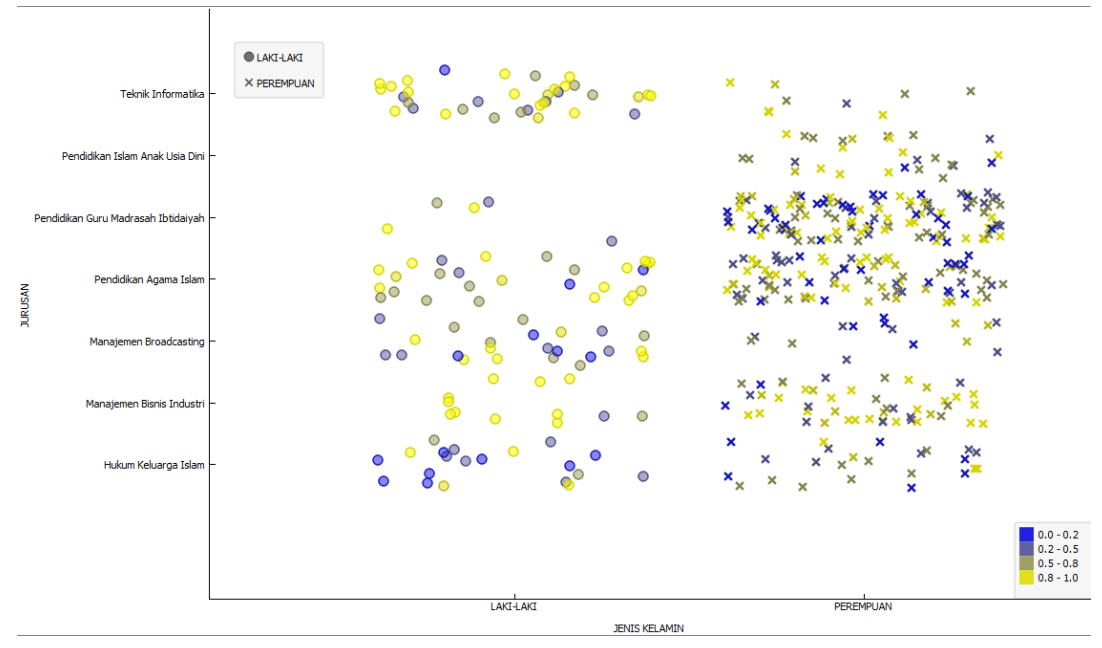

Gambar 6. Visualisasi data penerimaan teknologi berdasarkan demografis

Pada aspek terakhir adalah kebutuhan pelatihan. Kebutuhan pelatihan pada penelitian ini menunjukkan bahwa sebagian besar mahasiswa menyatakan kebutuhannnya untuk menerima pelatihan menggunakan pembelajaran online dimana nilai rata-rata yang diperoleh oleh responden laki-laki dan perempuan masingmasing sebesar 0,86. Hambatan - hambatan yang terjadi pada proses pembelajaran online adalah kurangnya kesiapan mahasiswa dalam menghadapi pembelajaran online karena hal tersebut mempengaruhi faktor aksesibilitas dan pembelajaran mandiri (Roddy et al., 2017). Oleh sebab itu maka pelatihan perlu dilaksanakan untuk meminimalisir hambatan yang terjadi. Visuali sebaran data aspek kebutuhan pelatihan dapat dilihat pada Gambar 7. 


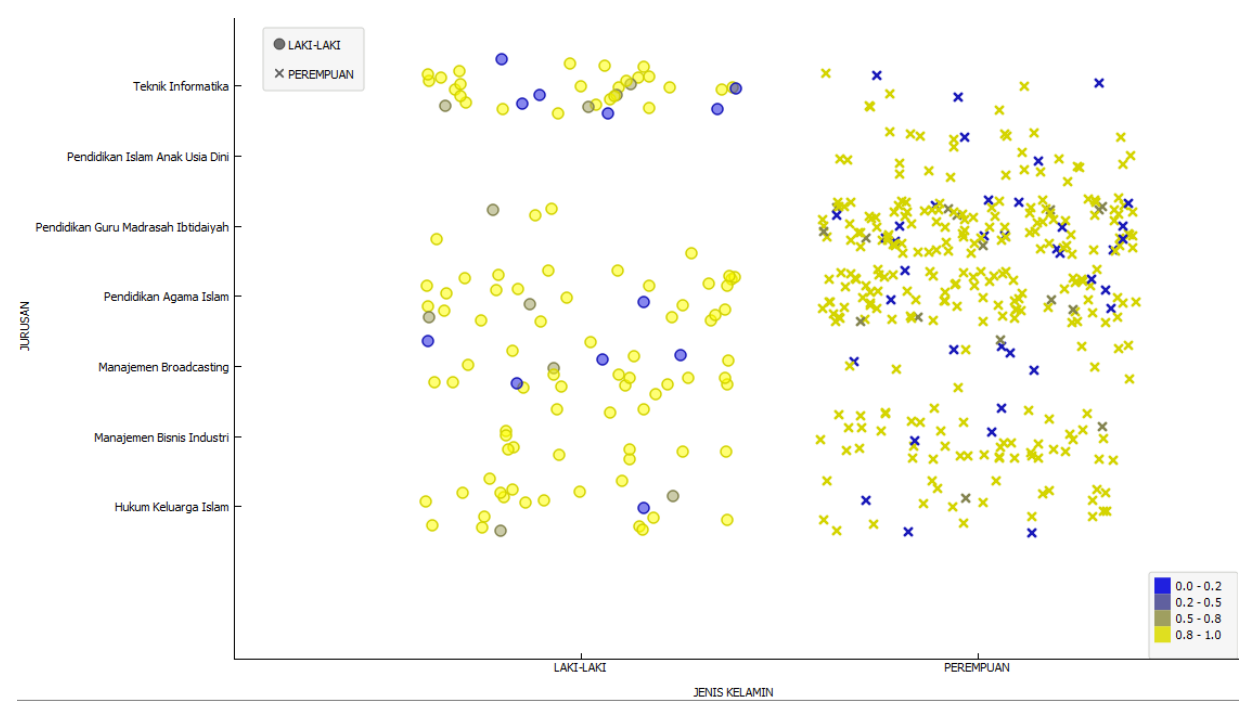

Gambar 7. Visualisasi data kebutuhan pelatihan berdasarkan demografis

Kesiapan mahasiswa dalam menghadapi pembelajaran online terdiri dari lima aspek yang perlu diperhatikan, namun dari aspek - aspek tersebut mahasiswa memiliki beberapa skala prioritas yang perlu dipertimbangkan berdasarkan nilai rata-rata keseluruhan aspek kesiapan pembelajaran online. Pertimbangan mahasiswa terkait aspek yang perlu dipertimbangkan adalah Tingkat Penggunaan Teknologi $(\bar{x}=0,82)$ dan Kebutuhan Pelatihan Pembelajaran Online $(\bar{x}=0,86)$. Tingkat penggunaan teknologi terkait bagaimana mahasiswa mengoptimalisasi peran teknologi dalam proses pembelajaran online. Penggunaan teknologi pada pembelajaran online dipergunakan untuk membangun dan merancang pengalaman belajar karena pembelajaran online mengacu kepada proses transfer pengetahuan dan pembelajaran (Coman, Țîru, MeseșanSchmitz, Stanciu, \& Bularca, 2020). Meskipun dalam penelitian lain, penggunaan teknologi dipengaruhi dengan motivasi intrinsik terhadap kesuksesan pembelajaran online seperti kemandirian, kepercayaan diri yang tinggi, dan minat belajar (Magen-Nagar \& Shonfeld, 2018). Selain itu kebutuhan terhadap pelatihan juga perlu diperhatikan untuk memberikan standard terhadap kemampuan awal mahasiswa saat akan mengikuti pembelajaran online. Pelatihan pembelajaran online diperlukan untuk meningkatkan pengembangan kompetensi dan mengeksplorasi penggunaan pembelajaran online (Letina, 2020). Berdasarkan penjabaran tersebut di atas maka dapat ditarik kesimpulan bahwa kesiapan pembelajaran online sangat diperlukan untuk mencapai produktivitas belajar.

\section{SIMPULAN}

Penelitian ini bertujuan untuk mengukur realibitas dan validitas pengukuran kesiapan pembelajaran online pada mahasiswa di perguruan tinggi. Tinjauan literatur secara sistematis yang dikaji menunjukkan bahwa terdapat beberapa aspek yang mempengaruhi tingkat kesiapan pembelajaran online dan adanya hubungan yang positif antara penggunaan teknologi, kepercayaan diri dan keberterimaan teknologi terhadap pembelajaran online. Penelitian ini menguji kerangka teoritis yang terdiri dari kesiapan pembelajaran online dan ekplorasi data demografis pada penggunaan pembelajara online. Hasil penelitian ini menunjukkan bahwa pengukuran kesiapan pembelajaran 
online memenuhi syarat reliabel yang ditunjukkan dengan nilai keandalan Cronbach's Alpha yang diperoleh lebih besar dari 0,60. Sedangkan validitas pengukuran kesiapan pembelajaran online pada penelitian ini dicapai yang ditunjukkan dengan nilai rhitung > rtabel yang dimiliki product moment sehingga dapat dinyatakan bahwa butir soal pada instrumen pengukuran dapat dinyatakan valid. Pada hasil eksplorasi data demografis didapatkan bahwa perbedaan gender tidak memberikan pengaruh signifikan terhadap aspek kesiapan pembelajaran online dibandingkan keberagaman program studi yang menjadi salahsatu faktor dari latar belakang studi mahasiswa.

Pada penelitian ini terdapat beberapa keterbatasan yang perlu diperhatikan yaitu data yang dikumpulkan hanya berasal dari beberapa program studi pada dua institusi perguruan tinggi. Dengan keterlibatan lebih banyak lagi perguruan tinggi dan program studi diharapkan dapat meningkatkan tingkat validitas tes. Kedua, pembahasan penelitian terbatas pada kajian yang bersifat kuantitatis sehingga perlu juga dilengkapi bagian kualitatif pada studi ini untuk mengetahui hambatan - hambatan pada pembelajaran online. Berdasarkan hasil kajian literatur yang dilakukan, masih sedikit sekali penelitian yang membahas faktor demografis terhadap pengujian instrumen pengukuran kesiapan pembelajaran online. Oleh sebab itu maka penelitian diperlukan untuk menguji validitas kesiapan pembelajaran online dengan latar belakang studi yang berbedabeda, jenis kelamin, dan usia yang beragam.

\section{DAFTAR RUJUKAN}

Akaslan, D., \& Law, E. L. C. (2011). Measuring student e-learning readiness: A case about the subject of electricity in higher education institutions in Turkey. International Conference on Web-Based Learning: Advances in Web-Based Learning -
ICWL 2011. Berlin: Springer, Berlin, Heidelberg.

https://doi.org/10.1007/978-3-642-

25813-8_22

Aydin, C. H., \& Tasci, D. (2005). Measuring readiness for e-learning: Reflections from an emerging country. Educational Technology and Society, 8(4).

Bakirtas, H., \& Akkas, C. (2017). Technology Readiness for New Technologies: an Empirical Study. Journal of International Social Research, 10(52). https://doi.org/10.17719/jisr.2017.1948

Benta, D., Bologa, G., Dzitac, S., \& Dzitac, I. (2015). University Level Learning and Teaching via E-Learning Platforms. Procedia Computer Science, 55(December). https://doi.org/10.1016/j.procs.2015.07 .123

Bovermann, K., Weidlich, J., \& Bastiaens, T. (2018). Online learning readiness and attitudes towards gaming in gamified online learning - a mixed methods case study. International Journal of Educational Technology in Higher Education, 15(1). https://doi.org/10.1186/s41239-0180107-0

Brace, N., Kemp, R., \& Snelgar, R. (2021). SPSS for Psychologists (7th ed.). London: Red Globe Press. https://doi.org/10.1007/978-1-13757923-2

Cai, Z., Fan, X., \& Du, J. (2017). Gender and attitudes toward technology use: A meta-analysis. Computers and Education, 105. https://doi.org/10.1016/j.compedu.201 6.11 .003

Chai, C. S., Koh, J. H. L., \& Tsai, C. C. (2013). A Review of Technological Pedagogical Content Knowledge Ching. Educational Technology and Society, 16(2).

Chung, E., Noor, N. M., \& Vloreen Nity Mathew. (2020). Are you ready? an assessment of online learning readiness among university students. International Journal of Academic Research in Business and Social Sciences, 9(1). https://doi.org/10.6007/IJARPED/v9- 
i1/7128

Coman, C., Țîru, L. G., Meseșan-Schmitz, L., Stanciu, C., \& Bularca, M. C. (2020). Online teaching and learning in higher education during the coronavirus pandemic: Students' perspective. Sustainability, 12(24). https://doi.org/10.3390/su122410367

Dray, B. J., Lowenthal, P. R., Miszkiewicz, M. J., Ruiz-Primo, M. A., \& Marczynski, K. (2011). Developing an instrument to assess student readiness for online learning: A validation study. Distance Education, 32(1). https://doi.org/10.1080/01587919.2011 .565496

Ferreira, J., Behrens, M., Torres, P., \& Marriott, R. (2018). The necessary knowledge for online education: Teaching and learning to produce knowledge. Eurasia Journal of Mathematics, Science and Technology Education, 14(6). https://doi.org/10.29333/ejmste/86463

FitzPatrick, T. (2012). Key Success Factors of eLearning in Education: A Professional Development Model to Evaluate and Support eLearning. USChina Education Review, 9.

Gagnon, D. A. (2014). Perceptions of Blended Learning: A Case Study on Student Experiences in an Advanced Placement Macroeconomics Course (Kennesaw State University). Kennesaw State University. Retrieved from http://digitalcommons.kennesaw.edu/i nstruceddoc_etd/1

Ghavifekr, S., \& Rosdy, W. A. W. (2015). Teaching and learning with technology: Effectiveness of ICT integration in schools. International Journal of Research in Education and Science, $1(2)$. https://doi.org/10.21890/ijres.23596

Gigdem, H., \& Osturk, M. (2016). Critical Components of Online Learning Readiness. Turkish Online Journal of Distance Education, 17(2).

Grove, S. K., Burns, N., \& Gray, J. R. (2013). Designs for Quantitative Nursing Research: Quick-Access Chart Descriptive Study Designs Correlational Study Designs Quasiexperimental Study Designs (7th ed.).
Missouri: Elsevier Saunders.

Hung, M.-L., Chou, C., Chen, C.-H., \& Own, Z.-Y. (2010). Learner readiness for online learning: Scale development and student perceptions. Computers and Education, 55(3). https://doi.org/10.1016/j.compedu.201 0.05 .004

Instructional Technology \& Distance Education Services. (2021). Necessary Technical Knowledge and Skills for Distance Learning. Retrieved May 8, 2021, from https://www.tamiu.edu/distance/studen ts/knowledge-and-skills.shtml

Joosten, T., \& Cusatis, R. (2020). Online Learning Readiness. American Journal of Distance Education, 34(3). https://doi.org/10.1080/08923647.2020 .1726167

Kadry, S., \& El-Hami, A. (2016). ESystems for The 21st Century: Concept, Developments, And Applications (2nd ed.). Oakville: CRC Press.

Kamdi, W. (2017). Inovasi Pembelajaran Teknik dan Vokasi: Antisipasi terhadap Perubahan. Malang.

Kementerian Pendidikan dan Kebudayaan. (2020). Surat Edaran Nomor 1 Tahun 2020 tentang Pencegahan Penyebaran Corona Virus Disease (Covid-19) di Perguruan Tinggi, Kementerian Pendidikan dan Kebudayaan. Retrieved from http://kemdikbud.go.id/main/?lang=id

Kementrian Kesehatan Republik Indonesia. (2020). Keputusan Menteri Kesehatan Republik Indonesia. Keputusan Menteri Kesehatan Republik Indonesia Nomor Hk.01.07/Menkes/413/2020 Tentang Pedoman Pencegahan Dan Pengendalian Coronavirus Disease 2019 (Covid-19). Indonesia.

Kuo, Y. C., Walker, A. E., Belland, B. R., Schroder, K. E. E., \& Kuo, Y. T. (2014). A case study of integrating interwise: Interaction, internet selfefficacy, and satisfaction in synchronous online learning environments. International Review of Research in Open and Distance Learning, 15(1). https://doi.org/10.19173/irrodl.v15i1.1 664 
Lai, K.-W. (2011). Digital technology and the culture of teaching and learning in higher education. Australasian Journal of Educational Technology, 27(8). https://doi.org/10.14742/ajet.892

Letina, A. (2020). Development of students' learning to learn competence in primary science. Education Sciences, $10(11)$. https://doi.org/10.3390/educsci101103 25

Magen-Nagar, N., \& Shonfeld, M. (2018). The impact of an online collaborative learning program on students' attitude towards technology. Interactive Learning Environments, 26(5). https://doi.org/10.1080/10494820.2017 .1376336

Martin, F., \& Bolliger, D. U. (2018). Engagement Matters: Student Perceptions on the Importance of Engagement Strategies in the Online Learning Environment. Online Learning Journal, 22(1). https://doi.org/10.24059/olj.v22i1.109 2

Martin, F., Stamper, B., \& Flowers, C. (2020). Examining student perception of readiness for online learning: Importance and confidence. Online Learning Journal, 24(2). https://doi.org/10.24059/olj.v24i2.205 3

Muqsith, M. K. A., \& Zainiyati, H. S. (2021). Studi Komparasi Penggunaan Whatsapp dan Schoology terhadap Hasil Belajar di Masa Darurat. Jurnal Pendidikan Edutama), 8(1).

Noesgaard, S. S., Ørngreen, R., \& Foundation, K. (2015). The Effectiveness of E-Learning: An Explorative and Integrative Review of the Definitions, Methodologies and Factors that Promote e-Learning Effectiveness. Electronic Journal of ELearning, 13(4).

Padilla-Meléndez, A., Del Aguila-Obra, A. R., \& Garrido-Moreno, A. (2013). Perceived playfulness, gender differences and technology acceptance model in a blended learning scenario. Computers and Education, 63. https://doi.org/10.1016/j.compedu.201 2.12.014

Rasouli, A., Rahbania, Z., \& Attaran, M.
(2016). Students' Readiness for Elearning Application in Higher Education. Malaysian Online Journal of Educational Technology, 4(3).

Rhee, B. Van Der, Verma, R., Plaschka, G. R., \& Kickul, J. R. (2007). Technology Readiness, Learning Goals, and eLearning: Searching for Synergy. Decision Sciences Journal of Innovative Education, 5(1). Retrieved from

https://onlinelibrary.wiley.com/doi/abs /10.1111/j.1540-4609.2007.00130.x

Roddy, C., Amiet, D. L., Chung, J., Holt, C., Shaw, L., McKenzie, S., ... Mundy, M. E. (2017). Applying Best Practice Online Learning, Teaching, and Support to Intensive Online Environments: An Integrative Review. Frontiers in Education, 2(November). https://doi.org/10.3389/feduc.2017.000 59

Saadé, R. G., Kira, D., Mak, T., \& Nebebe, F. (2017). Anxiety and Performance in Online Learning. Proceedings of the Informing Science and Information Technology Education Conference, (April). Ho Chi Minh City: Informing Science Institute. https://doi.org/10.28945/3736

Sadik, A. (2008). Digital storytelling: A meaningful technology-integrated approach for engaged student learning. Educational Technology Research and Development, $56(4)$. https://doi.org/10.1007/s11423-0089091-8

Santosa, E. B., \& Sarwanta, S. (2021). Pengaruh Tingkat Internet SelfEfficacy, Pengalaman Mengajar dan Usia Guru Terhadap Peguasaan Komputer dalam Strategi Pembelajaran Daring. Jurnal Pendidikan Edutama, 8(1). https://doi.org/10.30734/jpe.v8i1.1489

Siddiquah, A., \& Salim, Z. (2017). The ICT facilities, skills, usage, and the problems faced by the students of higher education. Eurasia Journal of Mathematics, Science and Technology Education, 13(8). https://doi.org/10.12973/eurasia.2017. 00977a

Simmering, M. J., Posey, C., \& Piccoli, G. (2009). Computer Self-Efficacy and 
Motivation to Learn in a Self-Directed Online Course. Decision Sciences Journal of Innovative Education, 7(1). https://doi.org/10.1111/j.15404609.2008.00207.x

Somayeh, M., Dehghani, M., Mozaffari, F., Ghasemnegad, S. M., Hakimi, H., \& Samaneh, B. (2016). The effectiveness of E- learning in learning: A review of the literature. International Journal of Medical Research \& Health Sciences, $5(2)$.

Souter, D. (2017). Internet Access and Education: Key considerations for policy makers. In Internet Society.

Tsourela, M., \& Roumeliotis, M. (2015). The moderating role of technology readiness, gender, and sex in consumer acceptance and actual use of Technology-based services. Journal of High Technology Management Research, 26(2). https://doi.org/10.1016/j.hitech.2015.0 9.003

Turugare, M., \& Rudhumbu, N. (2020). Integrating technology in teaching and learning in universities in Lesotho: opportunities and challenges. Education and Information Technologies, 25. https://doi.org/10.1007/s10639-01910093-3

Ünal, Y., Alir, G., \& Soydal, İ. (2014). Students readiness for e-learning: An assessment on hacettepe university department of information management. Communications in Computer and Information Science, 423. https://doi.org/10.1007/978-3662-44412-2_13

Valencia-Vallejo, N., López-Vargas, O., \& Sanabria-Rodríguez, L. (2016). SelfEfficacy in Computer-Based Learning Environments: A Bibliometric Analysis. Psychology, 07(14). https://doi.org/10.4236/psych.2016.71 4170

Yang, S., \& Kwok, D. (2017). A study of students' attitudes towards using ict in a social constructivist environment. Australasian Journal of Educational Technology, $33(5)$. https://doi.org/10.14742/ajet.2890 